\title{
Effect of Post-harvest Degreening on Vitamin-C Content of Acid Lime Cv. Balaji
}

\author{
Pooja Yaddanapudi ${ }^{\text {** }}$ and A. Kiran Kumar ${ }^{2}$ \\ ${ }^{1}$ Department of Fruit Science, Ph. D. Scholar, Sri Konda Laxman Telangana State \\ Horticultural University, ${ }^{2}$ Department of Fruit Science, College of Horticulture, \\ Rajendranagar, Hyderabad, Telangana State, India \\ *Corresponding author
}

\section{A B S T R A C T}

\begin{tabular}{l} 
Ke y w o r d s \\
Acid lime, Cv. \\
Balaji, \\
Degreening, \\
Vitamin- C \\
\hline Article Info \\
$\begin{array}{l}\text { Accepted: } \\
\text { 12 September } 2020 \\
\text { Available Online: } \\
10 \text { October } 2020\end{array}$ \\
\hline
\end{tabular}

\section{Introduction}

Vitamin- $\mathrm{C}$ is required for a range of essential metabolic reactions in all animals and plants. Deficiency of this vitamin causes the disease scurvy. As Vitamin-C is needed for the growth and repair of tissues in all parts of our body and it is used to form an important protein used to make skin, tendons, ligaments and blood vessels, heal wounds and form scar tissues, repair and maintaining cartilage, bones and teeth. It is one of the many antioxidants, which removes free radicals and stimulate the immune system and prevents and treat cancers. The body is not able to
Aim of present investigation was analyse the effect of post-harvest degreening with ethylene on Vitamin C content of Acid lime Cv. Balaji. The present research was conducted at Post-harvest laboratory, college of horticulture, Sri Konda Laxman Telangana State Horticultural University, Rajendranagar, Hyderabad, during the year 2018-2019. Degreening experiment was designated with factorial completely randomized design with two factors viz., (A) Ethylene concentrations, (B) Number of pulsings. Vitamin $\mathrm{C}$ is most important among the quality parameters of citrus fruits. This investigation concluded that the Vitamin-C content of Acid lime Cv. Balaji declined with , treatment but, the effect of ethylene was not directly on Vitamin-C, which decreases with ripening. 10-15ppm ethylene with shortest exposure times gives the uniform degreening and good levels of Vitamin C. 


\section{Materials and Methods}

\section{Acid lime Cv. Balaji fruits}

Acid lime Cv. Balaji (Citrus aurantifolia S.) fruits were collected from citrus orchard. Matured fruits are harvested manually and immediately transported to degreening chamber and subjected to the ethylene treatments at room temperature $27-28{ }^{\circ} \mathrm{C}$. Treated fruits were stored up to 16 days. Some treatments were spoiled after 12 days of storage. Their mean values were recorded.

\section{Ethylene cylinder}

Ethylene release canisters named Ripylene, manufactured by Chemtron science laboratories, Mumbai were used in the research. 15 grams of ethylene gas was filled in a cylinder with adjustable gauge. This was approved by National Horticulture Board, Food Safety and Standards Authority of India and Food and Drug Administration as a gas for ripening.

\section{Low-cost ripening chamber}

The low-cost ripening chamber consists of 40mm PUF (Polyurethane Foam) insulated panels with PPGI Sheets (Pre painted Galvanised Iron) lamination on either side, with flashings and swing door - $300 \times 600$ $\mathrm{mm}$ with the capacity of 5 crates $(100 \mathrm{~kg})$.

\section{Experimental Details}

Experiment was designated with two factorial completely randomized design and executed with the objective: effect of post-harvest degreening on Vitamin-C content of Acid lime Cv. Balaji. Acid lime Cv. Balaji fruits were allowed to degreen in Low Cost Ripening Chamber with ethylene treatment with different levels of ethylene concentrations i.e. $\left(\mathrm{A}_{1}\right) 5 \mathrm{ppm}\left(\mathrm{A}_{2}\right)$ 10ppm
$\left(\mathrm{A}_{3}\right)$ 15ppm and $\left(\mathrm{A}_{4}\right)$ 20ppm were given four levels of number of pulsings viz., ( $\left.\mathrm{B}_{1}\right) 6$ pulsings in $24 \mathrm{hrs} @ 4 \mathrm{hrs}$. interval $\left(\mathrm{B}_{2}\right) 4$ pulsings in 24 hrs @ 6 hrs. interval $\left(\mathrm{B}_{3}\right) 2$ pulsings in $24 \mathrm{hrs} @ 12 \mathrm{hrs}$. interval and $\left(\mathrm{B}_{4}\right)$ 1 pulsing in 24 hrs @ 24 hrs. interval. The combination of 2 factors gives 16 treatments viz.,

$\mathrm{T}_{1} .5 \mathrm{ppm}$ ethylene with 6 pulsings in $24 \mathrm{hrs}$ @ 4 hrs interval

$\mathrm{T}_{2} .5 \mathrm{ppm}$ ethylene with 4 pulsings in $24 \mathrm{hrs}$ @ 6 hrs interval

$\mathrm{T}_{3} .5 \mathrm{ppm}$ ethylene with 2 pulsings in $24 \mathrm{hrs}$ @ 12 hrs interval

T. 5 ppm ethylenewith1 pulsing in 24 hrs @ $24 \mathrm{hrs}$ interval

$\mathrm{T}_{5} .10 \mathrm{ppm}$ ethylene with 6 pulsings in $24 \mathrm{hrs}$ @ 4 hrs interval

$\mathrm{T}_{6} .10 \mathrm{ppm}$ ethylene with 4 pulsings in $24 \mathrm{hrs}$ @ 6 hrs interval

$\mathrm{T}_{7} .10 \mathrm{ppm}$ ethylene with 2 pulsings in $24 \mathrm{hrs}$ @ 12 hrs interval

$\mathrm{T}_{8} .10 \mathrm{ppm}$ ethylene with 1 pulsing in $24 \mathrm{hrs}$ @ 24 hrs interval

$\mathrm{T}_{9} .15 \mathrm{ppm}$ ethylene with 6 pulsings in $24 \mathrm{hrs}$ @ 4 hrs interval

$\mathrm{T}_{10} .15 \mathrm{ppm}$ ethylene with 4 pulsings in $24 \mathrm{hrs}$ @ 6 hrs interval

$\mathrm{T}_{11} .15 \mathrm{ppm}$ ethylene with 2 pulsings in $24 \mathrm{hrs}$ @ 12 hrs interval

$\mathrm{T}_{12} .15 \mathrm{ppm}$ ethylene with 1 pulsing in $24 \mathrm{hrs}$ @ 24 hrs interval

$\mathrm{T}_{13} .20 \mathrm{ppm}$ ethylene with 6 pulsings in $24 \mathrm{hrs}$ 
@ 4 hrs interval

$\mathrm{T}_{14} .20$ ppm ethylene with 4 pulsings in $24 \mathrm{hrs}$ @ 6 hrs interval

$\mathrm{T}_{15} .20 \mathrm{ppm}$ ethylene with 2 pulsings in $24 \mathrm{hrs}$ @ 12 hrs interval

$\mathrm{T}_{16} .20$ ppm ethylene with 1 pulsing in $24 \mathrm{hrs}$ @ 24 hrs interval

\section{Details of control}

Vitamin C (mg/100g) values of Acid lime Cv. Balaji fruits after harvest without subjecting to ethylene (control) were recorded. The values were $49.99,49.92$ and 42.88 on $1^{\text {st }}, 4^{\text {th }}$ and $8^{\text {th }}$ day respectively.

\section{Vitamin-C (mg/100g): Ascorbic acid (mg/100g)}

Ascorbic acid was estimated by the procedure elicited by Ranganna (1987). Ten grams of fruit tissue was blended in $3 \%$ metaphosphoric acid and the volume was made up to $100 \mathrm{ml}$ of $\mathrm{H}_{3} \mathrm{PO}_{4}$. The contents were filtered through Whatman No.1 filter paper and $10 \mathrm{ml}$ of the aliquot was taken and titrated with standard dye (2, 6-dichlorophenolindophenol dye) to a pink end point. The ascorbic acid was expressed as $\mathrm{mg}$ ascorbic acid/100 g. Ascorbic acid was calculated by using following formula.

Ascorbic Acid : $=\frac{\text { Titre Value } \times \text { Dye Factor } \times \text { Volume Made Up } \times 100}{\text { Aliquot Taken for Estimation } \times \text { Weight of Sample for Estimation }}$

\section{Statistical analysis}

The design adopted was completely randomized design with 2 factors (ethylene dose and number of pulsings). All the analysis was performed in 3 replicates of samples and the results were presented as critical difference (CD) and standard deviation. The experimental data were subjected to (ANOVA) using module of ICAR CCARI WASP. Least significance difference
(Fisher's protected LSD) were calculated following significant $F$ test $(p=0.05)$. All assumptions of analysis were checked to ensure validity.

\section{Results and Discussion}

The data pertaining to Vitamin-C (mg/100g) of Acid lime $\mathrm{Cv}$. Balaji at ambient temperature as influenced by ethylene concentrations and number of pulsings in tables 1 to 4 and Figs. 1 and 2.

Effect of ethylene concentrations on Vitamin-C in acid lime Cv. Balaji

On $4^{\text {th }}$ day (Table 1.) among the ethylene concentrations significantly maximum level of Vitamin-C was recorded with ethylene @ 5 ppm (49.89 mg/100g) followed by ethylene @ 10 ppm $(47.63 \mathrm{mg} / 100 \mathrm{~g})$ while, lowest with $20 \mathrm{ppm}(44.53 \mathrm{mg} / 100 \mathrm{~g})$. On $8^{\text {th }}$ day (Table 2.) among the ethylene concentrations significantly maximum level of Vitamin-C was recorded with ethylene @ 5 ppm (42.50 $\mathrm{mg} / 100 \mathrm{~g})$ followed by $10 \mathrm{ppm}$ (41.78 $\mathrm{mg} / 100 \mathrm{~g})$ while, lowest with 20 ppm (38.69 $\mathrm{mg} / 100 \mathrm{~g}$ ).

\section{Effect of number of pulsings on Vitamin-C in acid lime $\mathrm{Cv}$. Balaji}

On $4^{\text {th }}$ day (Table 1.) among the time of pulsing significantly maximum level of Vitamin-C was recorded with 1 pulsing in 24 hrs @ 24 hrs interval (47.59 mg/100g), followed by 2 pulsings in $24 \mathrm{hrs} @ 12 \mathrm{hrs}$ interval (47.01 mg/100g) while, lowest with 6 pulsings in $24 \mathrm{hrs} @ 4 \mathrm{hrs}$ interval (46.55 $\mathrm{mg} / 100 \mathrm{~g})$. On $8^{\text {th }}$ day (Table 2.) among the time of pulsing significantly maximum level of Vitamin-C was recorded with 1 pulsing in 24 hrs @ 24 hrs interval (41.24 mg/100g), followed by 2 pulsings in 24 hrs @ 12 hrs interval $(40.98 \mathrm{mg} / 100 \mathrm{~g})$ while, lowest with 6 pulsings in 24 hrs @ 4 hrs interval (40.26 $\mathrm{mg} / 100 \mathrm{~g}$ ). 
Interaction effect of ethylene concentrations and number of pulsings on Vitamin-C in Acid lime Cv. Balaji

Among the storage days $4^{\text {th }}$ and $8^{\text {th }}$ day interaction between ethylene concentration and number of pulsings were significantly differed. On $4^{\text {th }}$ day significantly maximum level of Vitamin-C was noticed in 5ppm ethylene with 1 pulsing in 24 hrs@ 24 hrs interval $(49.98 \mathrm{mg} / 100 \mathrm{~g}) .5 \mathrm{ppm}$ ethylene with 2 pulsings in $24 \mathrm{hrs} @ 12 \mathrm{hrs}$ interval (49.92 $\mathrm{mg} / 100 \mathrm{~g}), 5 \mathrm{ppm}$ ethylene with 4 pulsings in 24 hrs@6 hrs interval (49.86 mg/100g) and 5ppm ethylene with 6 pulsings in 24 hrs@ 4 hrs interval $(49.81 \mathrm{mg} / 100 \mathrm{~g})$ were at par with 5ppm ethylene with 1 pulsing in 24 hrs@ 24 hrs interval $(49.98 \mathrm{mg} / 100 \mathrm{~g})$ while, minimum in 20ppm ethylene with 6 pulsings in 24 hrs@ $4 \mathrm{hrs}$ interval $(43.73 \mathrm{mg} / 100 \mathrm{~g})$. On $8^{\text {th }}$ day significantly maximum level of Vitamin-C was noticed in 5ppm ethylene with 1 pulsing in 24 hrs@ 24 hrs interval (42.86 mg/100g) followed by $5 \mathrm{ppm}$ ethylene with 2 pulsings in 24 hrs@ 12 hrs interval (42.64 mg/100g). 10ppm ethylene with 1 pulsing in 24 hrs@ 24 hrs interval $(42.03 \mathrm{mg} / 100 \mathrm{mg})$ was at par with 5ppm ethylene with 6 pulsings in $24 \mathrm{hrs}$ @ 4 hrs interval (42.17 mg/100mg) while, lowest in 20ppm ethylene with 6 pulsings in 24 hrs@ 4 hrs interval (38.24 mg/100g). The mean values recorded in the Vitamin-C of Acid lime Cv. Balaji fruits at $12^{\text {th }}$ day and $16^{\text {th }}$ day during storage tabulated at Table 3 and 4 respectively. A similar decreasing trend in respect of Vitamin-C was observed.

Vitamin $\mathrm{C}$ is among the most important quality parameters for fruits. In present investigation, vitamin $\mathrm{C}$ content was decreased with an increase in storage time. Degreening process promotes the conversion of acids to sugars leads to decrease in the Vitamin-C content (Bisen et al., 2012).

With the advancement of storage period, total soluble solids were increased while Vitamin$\mathrm{C}$ and acidity of fruits decreased in Kagzi lime (Piyush and Dashora, 2000). It is evident from the data that, Vitamin-C content of lime fruits was gradually decreased with the time (Ayesha et al., 2014).

Table.1 Ascorbic acid (mg/100g): of Acid lime Cv. Balaji as influenced by ethylene concentrations and number of pulsings per $24 \mathrm{hrs}$. at ambient temperature on $4^{\text {th }}$ day

\begin{tabular}{|l|c|c|c|c|c|}
\hline \multirow{2}{*}{$\begin{array}{l}\text { Ethylene } \\
\text { concentrations }\end{array}$} & \multicolumn{5}{|c|}{ Number of pulsings per 24 hrs. } \\
\hline Ethylene @ 5ppm & 49.81 & 49.86 & 49.92 & 49.98 & $49.89^{\mathrm{A}}$ \\
\hline Ethylene @ 10ppm & 47.18 & 47.22 & 47.46 & 48.64 & $47.63^{\mathrm{B}}$ \\
\hline Ethylene @ 15ppm & 45.49 & 45.62 & 45.93 & 46.42 & $45.87^{\mathrm{C}}$ \\
\hline Ethylene @ 20ppm & 43.73 & 44.33 & 44.74 & 45.33 & $44.53^{\mathrm{D}}$ \\
\hline Mean & $46.55^{\mathrm{d}}$ & $46.76^{\mathrm{c}}$ & $47.01^{\mathrm{b}}$ & $47.59^{\mathrm{a}}$ & \\
\hline Factors & CD (5\%) & SEm \pm & & \\
\hline $\begin{array}{l}\text { Ethylene concentrations } \\
\text { (A) }\end{array}$ & 0.07 & 0.03 & & \\
\hline Number of pulsings (B) & 0.07 & & 0.03 & & \\
\hline Factor A $\times$ B & 0.15 & 0.05 & & \\
\hline
\end{tabular}


Table.2 Ascorbic acid (mg/100g) of Acid lime Cv. Balaji as influenced by ethylene concentrations and number of pulsings per $24 \mathrm{hrs}$. at ambient temperature on $8^{\text {th }}$ day

\begin{tabular}{|l|l|l|l|l|l|}
\hline \multirow{2}{*}{$\begin{array}{l}\text { Ethylene } \\
\text { concentrations }\end{array}$} & \multicolumn{5}{|c|}{ Number of pulsings per 24 hrs. } \\
\hline Ethylene @ 5ppm & 42.17 & 42.32 & 42.64 & 42.86 & $42.50^{\mathrm{A}}$ \\
\hline Ethylene @ 10ppm & 41.32 & 41.86 & 41.91 & 42.03 & $41.78^{\mathrm{B}}$ \\
\hline Ethylene @ 15ppm & 39.32 & 39.62 & 40.64 & 40.86 & $40.11^{\mathrm{C}}$ \\
\hline Ethylene @ 20ppm & 38.24 & 38.59 & 38.71 & 39.22 & $38.69^{\mathrm{D}}$ \\
\hline Mean & $40.26^{\mathrm{d}}$ & $40.59^{\mathrm{c}}$ & $40.98^{\mathrm{b}}$ & $41.24^{\mathrm{a}}$ & \\
\hline Factors & $\mathbf{C D}(\mathbf{5 \%})$ & $\mathbf{S E m} \pm$ & & \\
\hline $\begin{array}{l}\text { Ethylene concentrations } \\
\text { (A) }\end{array}$ & 0.14 & 0.05 & & \\
\hline Number of pulsings (B) & 0.14 & & 0.05 & & \\
\hline Factor A $\times \mathbf{B}$ & 0.28 & 0.10 & & \\
\hline
\end{tabular}

Table.3 Ascorbic acid (mg/100g) of Acid lime Cv. Balaji as influenced by ethylene concentrations and number of pulsings per $24 \mathrm{hrs}$. at ambient temperature on $12^{\text {th }}$ day

\begin{tabular}{|l|l|l|l|l|}
\hline \multirow{2}{*}{$\begin{array}{l}\text { Ethylene } \\
\text { concentrations }\end{array}$} & \multicolumn{4}{|c|}{ Number of pulsings per 24 hrs. } \\
\hline Ethylene @5ppm & 6 pulsings & 4 pulsings & 2 pulsings & 1 pulsing \\
\hline Ethylene @ 10ppm & - & - & - & - \\
\hline Ethylene @ 15ppm & 39.35 & 40.55 & - & - \\
\hline Ethylene @ 20ppm & 38.47 & 38.95 & 39.28 & 39.85 \\
\hline
\end{tabular}

Table.4 Ascorbic acid (mg/100g) of Acid lime Cv. Balaji as influenced by ethylene concentrations and number of pulsings per $24 \mathrm{hrs}$. at ambient temperature on $16^{\text {th }}$ day

\begin{tabular}{|l|c|c|c|c|}
\hline \multirow{2}{*}{$\begin{array}{l}\text { Ethylene } \\
\text { concentrations }\end{array}$} & \multicolumn{4}{|c|}{ Number of pulsings per 24 hrs. } \\
\hline Ethylene @5ppm & - & - & - & - \\
\hline Ethylene @ 10ppm & - & - & - & - \\
\hline Ethylene @ 15ppm & - & 36.61 & 38.56 & - \\
\hline Ethylene @ 20ppm & - & - & - & - \\
\hline
\end{tabular}


Fig.1 Ascorbic Acid (mg/100g) of Acid lime Cv. Balaji as influenced by different ethylene concentrations and number of pulsings per $24 \mathrm{hrs}$. at ambient temperature

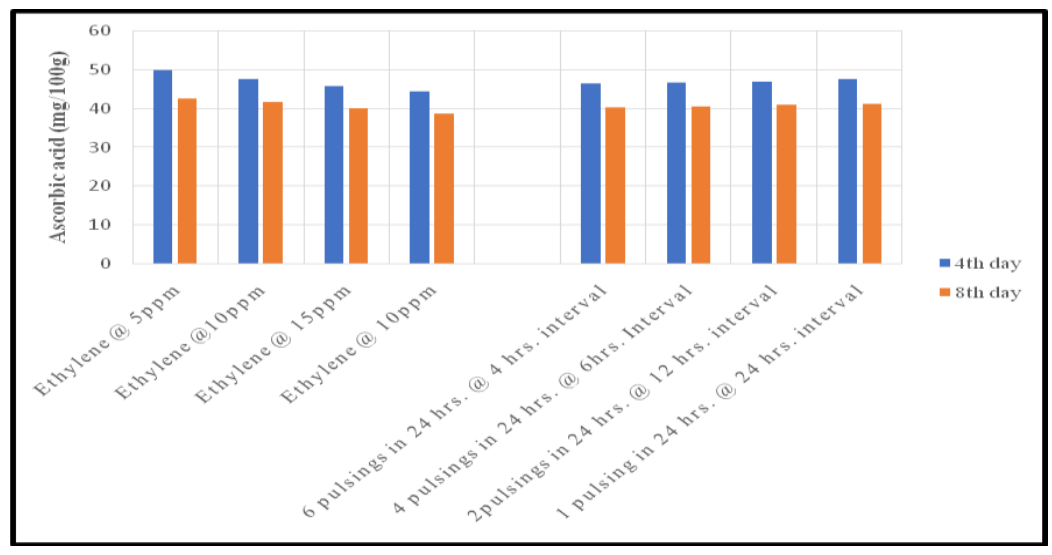

Fig.2 Ascorbic Acid (mg/100g) of Acid lime Cv. Balaji as influenced by interaction between ethylene concentrations and number of pulsings per $24 \mathrm{hrs}$. at ambient temperature on $4^{\text {th }}, 8^{\text {th }}$, $12^{\text {th }}$ and $16^{\text {th }}$ day

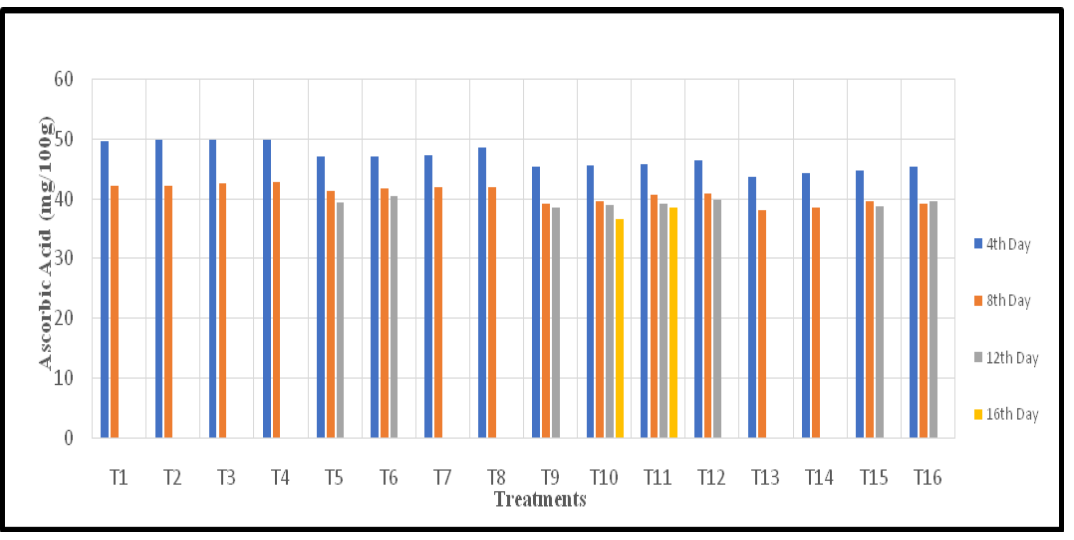

In the present investigation among the ethylene concentrations $15 \mathrm{ppm}$ and $20 \mathrm{ppm}$ show good degreening but, 20ppm ethylene drastically reduces the vitamin-C content due the high rate of respiration. Among the time of pulsings 1 pulsing in $24 \mathrm{hrs}$. and 2 pulsings in 24 hrs. were better regarding the Vitamin-C content. So, $15 \mathrm{ppm}$ ethylene with 1pulsing in $24 \mathrm{hrs}$. and 2 pulsings in $24 \mathrm{hrs}$. were best treatments. They give uniform degreening and no effect on recovery of vitamin-C. The present investigation was agreement with Ladaniya and Shyam (2001). They were reported that the Vitamin-C content of sweet orange declined with ethylene treatment but, the effect of ethylene was not directly on Vitamin-C, which decreases with ripening.

Similar results were reported by Jadhao et al., (2008) and Bisen et al., (2012). Where vitamin $\mathrm{C}$ content was slightly reduced during the storage. the decline in vitamin $\mathrm{C}$ content seems to be caused by the oxidation of Vitamin-C by enzymes.

In conclusion the degreening process promotes the conversion of acids to sugars leads to decrease in the Vitamin-C content. Therefore, degreening must be performed under appropriate conditions, using the lowest 
possible levels of ethylene i.e., 10ppm and $15 \mathrm{ppm}$ and shortest possible exposure timesi.e., 1 pulsing in 24hrs. @ 24hrs. interval and 2 pulsings in 24hrs. @ 12hrs. interval. Finally, to conclude $15 \mathrm{ppm}$ ethylene with 1pulsing in 24 hrs. @ 24 hrs. interval and 15 ppm ethylene with 2 pulsings in 24 hrs. @ 12 hrs. interval were best treatments. They give uniform degreening and no effect on recovery of vitamin-C.

\section{Acknowledgement}

I express my profound sense of gratitude and heartfelt thanks to Post-harvest Laboratory, College of Horticulture, Rajendranagar, Hyderabad for providing equipment and necessary infrastructure throughout the research.

\section{References}

Ayesha, H, Anjan, K.S. and Mishra, P.K. 2014.Studies on ascorbic acid (vitamin-c) content in different citrus fruits and its degradation during storage. Science \& Culture.80: 265268.

Bisen, A, Pandey S.K. and Patel, N. 2012. Effect of Skin Coatings on Prolonging Shelf Life of Kagzi Lime Fruits
(Citrus aurantifolia S.). Journal of Food Science Technology. 49(6): 753759.

Grierson, W. and Newhall, W.F. 1960.Degreening of florida Citrus fruits. Florida Agricultural Experiment Stations. Bulletin: 620.

Jadhao, S.D, Borkar, P.A, Borkar, S.L, Bakane, P.H. and Murumkar, R.P. 2008. Effect of Different Treatments and Packaging Materials on Biochemical Changes during Storage of Kagzi Lime. Asian Journal of Biological Sciences.3: 247-250.

Ladaniya, M.S. and Singh, S. 2001. Use of ethylene gas for degreening of sweet orange (Citrus sinesisosbeck) cv. Mosambi. Journal of Scientific and Industrial Research. 60: 662-667.

Piyush, V. and Dashora, L.K. 2000.Postharvest physiconutritional changes in Kagzi limes (Citrus aurantifoliaS.) treated with selected oil emulsions and diphenyl. Plant Foods for Human Nutrition. 55: 279-284.

Ranganna, S. 1987. Manual of Analysis of Fruit and Vegetable Products. Tata Mc Graw Pub. Co., New Delhi, India. pp. 9-15.

\section{How to cite this article:}

Pooja Yaddanapudi and Kiran Kumar, A. 2020. Effect of Post-harvest Degreening on VitaminC Content of Acid Lime Cv. Balaji. Int.J.Curr.Microbiol.App.Sci. 9(10): 1463-1469. doi: https://doi.org/10.20546/ijcmas.2020.910.174 